University of Nebraska - Lincoln

DigitalCommons@University of Nebraska - Lincoln

Publications from USDA-ARS / UNL Faculty

U.S. Department of Agriculture: Agricultural

Research Service, Lincoln, Nebraska

2005

\title{
Induction of redox sensitive extracellular phenolics during plant-bacterial interactions
}

\author{
C. Jacyn Baker \\ United States Department of Agriculture, jacyn.baker@ars.usda.gov \\ Bruce D. Whitaker \\ United States Department of Agriculture \\ Daniel P. Roberts \\ United States Department of Agriculture, dan.roberts@ars.usda.gov \\ Norton M. Mock \\ United States Department of Agriculture \\ Clifford P. Rice \\ United States Department of Agriculture \\ See next page for additional authors
}

Follow this and additional works at: https://digitalcommons.unl.edu/usdaarsfacpub

Part of the Agricultural Science Commons

Baker, C. Jacyn; Whitaker, Bruce D.; Roberts, Daniel P.; Mock, Norton M.; Rice, Clifford P.; Deahl, Kenneth L.; and Aver'yanov, Andrey A., "Induction of redox sensitive extracellular phenolics during plant-bacterial interactions" (2005). Publications from USDA-ARS / UNL Faculty. 338.

https://digitalcommons.unl.edu/usdaarsfacpub/338

This Article is brought to you for free and open access by the U.S. Department of Agriculture: Agricultural Research Service, Lincoln, Nebraska at DigitalCommons@University of Nebraska - Lincoln. It has been accepted for inclusion in Publications from USDA-ARS / UNL Faculty by an authorized administrator of DigitalCommons@University of Nebraska - Lincoln. 


\section{Authors}

C. Jacyn Baker, Bruce D. Whitaker, Daniel P. Roberts, Norton M. Mock, Clifford P. Rice, Kenneth L. Deahl, and Andrey A. Aver'yanov 


\title{
Induction of redox sensitive extracellular phenolics during plant-bacterial interactions ${ }^{2 /}$
}

\author{
C. Jacyn Baker ${ }^{\mathrm{a}, *}$, Bruce D. Whitaker ${ }^{\mathrm{b}}$, Daniel P. Roberts ${ }^{\mathrm{c}}$, Norton M. Mock ${ }^{\mathrm{a}}$, \\ Clifford P. Rice ${ }^{\mathrm{d}}$, Kenneth L. Deahl ${ }^{\mathrm{e}}$, Andrey A. Aver'yanov ${ }^{\mathrm{f}}$ \\ ${ }^{a}$ Molecular Plant Pathology Lab., US Department of Agriculture, Bldg. 004 Rm. 119, 10300 Baltimore Avenue, Beltsville, MD 20705, USA \\ ${ }^{\mathrm{b}}$ Produce Quality and Safety Lab., US Department of Agriculture, Beltsville, MD 20705, USA \\ ${ }^{\mathrm{c}}$ Sustainable Agricultural Systems Lab., US Department of Agriculture, Beltsville, MD 20705, USA \\ ${ }^{\mathrm{d}}$ Environmental Quality Lab., US Department of Agriculture, Beltsville, MD 20705, USA \\ ${ }^{\mathrm{e}}$ Vegetable Lab., US Department of Agriculture, Beltsville, MD 20705, USA \\ ${ }^{\mathrm{f}}$ Research Institute of Phytopathology, B. Vyazemy, Moscow region 143050, Russian Federation
}

Accepted 9 May 2005

\begin{abstract}
This study focuses on the transient and complex nature of phenolics that accumulate in the extracellular environment of plant suspension cells during the first few hours of the interaction between these plant cells and bacterial pathogens. Using suspension cells of Nicotiana tabacum we identified four acetophenones and four hydroxycinnamic acid amides that accumulate in this extracellular environment. Treatment of the suspension cells with isolates of the plant pathogen Pseudomonas syringae or heat-killed bacteria increased elicitation of extracellular phenolics and changed the composition of the compounds that accumulated. These phenolics were sensitive to oxidative stress; when suspension cells were treated with bacterial strains or elicitors that triggered an oxidative burst, these phenolics were oxidized and depleted for the duration of the burst. The qualitative and quantitative makeup of phenolics produced by $N$. tabacum suspensions was also affected by plant cell age and density. To our knowledge, this is the first study that closely follows the kinetics of individual extracellular phenolic compounds and the concurrent oxidative stress during the first few hours of a plant-bacterial interaction.
\end{abstract}

Published by Elsevier Ltd.

Keywords: Antioxidant capacity; Oxidative stress; Pseudomonas syringae; Nicotiana tabacum; Caffeoylputrescine; Feruloylputrescine; Hydroxyacetosyringone; Hydroxyacetovanillone; Acetosyringone; Feruloyltyramine

One of the unique aspects of plants is their ability to produce a broad variety of phenolic compounds. Known roles for these phenolics include phytoalexins for disease defense, lignin production for structural strength, and antioxidants to counter prooxidants produced during pathogen or environmental stresses $[10,23,29]$. In human and animal physiology, plant phenolics have been found to have a wide range of beneficial effects, which has led to

\footnotetext{
Mention of a trade name, proprietary product, or vendor does not constitute a guarantee of the product by the United States Department of Agriculture and does not imply its approval to the exclusion of other vendors that may also be suitable.

* Corresponding author. Tel.: +1 301504 5617; fax: +1 3015045449.

E-mail address: bakerc@ba.ars.usda.gov (C.J. Baker).
}

a renaissance in the search and study of bioactive plant phenolics [17,24,25,27]. Most of the medicinal properties attributed to plant extracts, such as anti-depression activity, anti-tumor activity and cardio-health, are linked to bioactive phenolics. For example, the plant phenolic acetosyringone has been shown to inhibit inflammation and asthma in humans through inhibition of both NADPH oxidases and actin polymerization in granulocytes [22]. Phenolics from Artemis vulgaris (mugwort) inhibit monoamine oxidase in the brain and can reduce depression [14]. It is becoming apparent that the physiological properties of phenolic metabolites goes beyond their 'antioxidative' characteristic.

A new role for phenolic compounds in plants is becoming evident especially relating to plant-microbe interactions. The animal studies mentioned above demonstrate that the bioactivity of phenolics can be due to the recognition of their unique and specific chemical structure 
by regulatory mechanisms. There are also several examples of this role for phenolics in plants. Acetosyringone, a phenolic produced at wound sites in plants, triggers vir gene transcription in the wound pathogen, Agrobacterium, allowing transfer of T-DNA to host cells [15]. In roots of nitrogen fixing plants, specific flavonoids activate nod genes in Rhizobium that are essential for establishing symbiosis $[26,33]$. In leaves, certain phenolic glucosides serve as signals that induce production of syringomycin toxin by Pseudomonas syringae pv. syringae [20]. These examples demonstrate that as intimate host-microbe associations evolved, phenolic metabolites were often selected to provide critical regulatory signals for the interaction.

With the exception of a few specific examples, the role of phenolics in the regulation of early plant-pathogen interactions has not been systematically examined. We have reported that extracellular phenolic antioxidants accumulated rapidly in suspension cells and attenuated the oxidative burst that often accompanies resistant plantbacterial interactions [7]. Further identification of these compounds revealed that they were not the typical phenolics normally associated with lignin synthesis, but that they belonged to groups of phenolics associated with bioactivity in both plants and animals. We recently reported that one of these phenolics, acetosyringone, was able to influence the timing of plant-bacterial recognition responses [6]. Because these extracellular plant phenolics accumulate in contact with bacterial pathogens and have been associated with bioactivity, we felt it was important to examine their role in host-pathogen interactions more critically. Here, in this first step, we report the qualitative and quantitative makeup of the individual phenolics during the first hours of the plantpathogen or plant-elicitor interaction. We also demonstrate their redox sensitivity and examine some parameters that affect their accumulation.

\section{Materials and methods}

\subsection{Chemicals}

Horseradish peroxidase (P-8250), guaiaicol (G-5502), and luminol and all other chemicals were purchased from Sigma-Aldrich Chemicals, Inc. (St Louis, MO), unless otherwise noted.

\subsection{Plant material}

Suspension cells of tobacco (Nicotiana tabacum L. cv. Hicks) were maintained and prepared as previously described [5]. Routinely, 2-day-old tobacco cultures were used for assays. Cells were washed and suspended in assay buffer, containing $0.5 \mathrm{mM} \mathrm{CaCl}_{2}, 0.5 \mathrm{mM} \mathrm{K}_{2} \mathrm{SO}_{4}, 175 \mathrm{mM}$ mannitol and $0.5 \mathrm{mM} \mathrm{MES} \mathrm{(pH} \mathrm{6).} \mathrm{Unless} \mathrm{otherwise} \mathrm{noted,}$ the cell density was $0.05 \mathrm{~g} \mathrm{ml}^{-1}$. Tobacco cell suspensions, $25 \mathrm{ml}$, in $50 \mathrm{ml}$ beakers, were equilibrated for $0.5 \mathrm{~h}$ in a rotary water bath shaker set at $27^{\circ} \mathrm{C}$ and $180 \mathrm{rpm}$ for tobacco cells. Treatments were added directly to the suspensions. The viability of tobacco cells remained constant during all experiments described as estimated by Evans Blue staining [4]. All experiments were preformed at least twice with two or more replicates per treatment.

\subsection{Bacterial preparations}

Cultures of Pseudomonas syringae pv. syringae 61 were maintained and prepared as previously described [5]. Isolate WT $(\mathrm{HR}+)$ causes a hypersensitive reaction when infiltrated into tobacco. Isolate B7 $(\mathrm{HR}-)$ is a Tn5 insertion mutant that does not induce a hypersensitive response [2]. Bacterial cultures were grown for $20 \mathrm{~h}$ in Kings B broth, centrifuged, washed and suspended in deionized water. Based on optical density, the concentration of the suspension was adjusted with water so that addition of about $200 \mu \mathrm{L}$ of the bacterial suspension to plant cell suspensions would result in the desired final concentration of bacteria, routinely $10^{7} \mathrm{cfu} \mathrm{ml}^{-1}$, unless otherwise noted. Bacterial concentrations in cell suspensions were verified periodically by dilution plating. Heat-killed preparations of isolate WT $(\mathrm{HR}+)$ were prepared as above and then autoclaved $20 \mathrm{~min}$ prior to treating cell suspensions.

\subsection{HPLC-UV quantification phenolics}

One-milliter samples of tobacco cell suspensions were filtered through Miracloth and centrifuged at 12,000 $\mathrm{g}$ for $5 \mathrm{~min}$ prior to HPLC analysis. When not analyzed immediately, samples were flushed with $\mathrm{N}_{2}$ and stored overnight at $-20{ }^{\circ} \mathrm{C}$. Phenolics were separated by $\mathrm{C}_{18} \mathrm{RP}-$ HPLC using a Waters (Milford, MA) quaternary pump, autosampler, photodiode array detector, and Empower data acquisition on a Dell Pentium 4 computer. A $250 \times 4.6 \mathrm{~mm}$ i.d., $5 \mu \mathrm{m}$ Luna C18(2) analytical column (Phenomenex, Torrence, CA) was used with a binary mobile phase gradient of methanol in $0.01 \%$ aqueous phosphoric acid as previously described [32]. Aliquots, $100 \mu \mathrm{L}$, of samples were acidified with phosphoric acid $(0.1 \%)$ and placed in the autosampler using a $30 \mu \mathrm{L}$ injection volume. Quantification of peak area was preformed using the $\mathrm{UV}_{\max }$ wavelength for each peak and reported as relative HPLC units.

\subsection{Identification of phenolics}

Atmospheric pressure ionization mass spectrometry analysis was performed on a Quattro LC benchtop triple quadrupole mass spectrometer (Micromass Ltd, Manchester, UK) using the electrospray ionization interface in the negative mode $\left(\mathrm{ES}^{-}\right)$as previously described [32]. Mass spectrometric data were acquired in the full scan mode over the $m / z$ 50-400 range. Sensitivity of the mass spectrometer was optimized using an acetosyringone standard. A Waters 2690 HPLC system using the same column and gradient as 
described for HPLC-UV analysis was utilized for separation of the phenolics. Samples of tobacco suspensions for mass spectroscopy were prepared as for HPLC-UV followed by acidification with phosphoric acid $(0.1 \%)$ and extraction with ethyl acetate. Dried samples were dissolved in methanol-water, (1:1, v/v) plus $0.1 \%$ formic acid, and $20 \mu \mathrm{L}$ injected per run with a Waters autosampler.

Phenolics isolated by HPLC-UV were dissolved in $0.8 \mathrm{ml}$ of $\mathrm{CD}_{3} \mathrm{OD}$, and ${ }^{1} \mathrm{H}-\mathrm{NMR}$ spectra were acquired deuterium locked at $25{ }^{\circ} \mathrm{C}$ using a Bruker QE $300 \mathrm{MHz}$ NMR spectrometer. Chemical shift values were assigned relative to the frequencies of residual nondeuterated water and methanol externally referenced to tetramethylsilane (TMS).

\subsection{Extracellular antioxidant assay}

The extracellular antioxidant capacity was estimated using a chemiluminescent assay that determined the quantity of $\mathrm{H}_{2} \mathrm{O}_{2}$ consumed by samples [5]. Samples $(0.4 \mathrm{ml})$ of treated or untreated suspension cells were dispensed into tubes, and placed into an EG and G Berthold Autolumat 953 luminometer (Bad Wildbad, Germany). Two stock solutions were prepared: (A) $0.5 \mathrm{mM} \mathrm{H}_{2} \mathrm{O}_{2}$ in the same assay buffer used for cell suspensions; and (B) horseradish peroxidase, $28.8 \mathrm{U} / \mathrm{ml}$, and $1.71 \mathrm{mM}$ luminol in $1 \mathrm{M} \mathrm{NaPO}_{4}, \mathrm{pH}$ 7. The luminometer first added stock solution $\mathrm{A}(50 \mu \mathrm{L})$ followed $4.5 \mathrm{~s}$ later by stock solution B

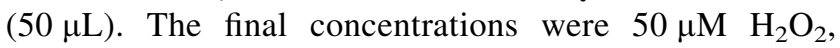
$1.44 \mathrm{U} / \mathrm{ml}$ of peroxidase and $171 \mu \mathrm{M}$ luminol. Chemiluminescence was measured as relative light units (RLU) every $0.1 \mathrm{~s}$ for $20 \mathrm{~s}$; the maximum measurement is proportional to the $\mathrm{H}_{2} \mathrm{O}_{2}$ concentration. Standard curves were prepared with dilutions of $\mathrm{H}_{2} \mathrm{O}_{2}$ in assay buffer. Under these assay conditions, the extracellular antioxidant in each sample had sufficient time to react with the added $\mathrm{H}_{2} \mathrm{O}_{2}$; the remaining $\mathrm{H}_{2} \mathrm{O}_{2}$ reacted with luminol. The decrease in RLU in suspension samples compared to buffer controls corresponds to the $\mathrm{H}_{2} \mathrm{O}_{2}$ consumed by extracellular antioxidant in each sample and provides an estimate of the extracellular antioxidant concentration of each sample.

\section{Results}

\subsection{Identification extracellular phenolics}

Eight extracellular phenolic compounds from $N$. tabacum cells were separated by $\mathrm{C}_{18}$-HPLC and identified on the basis of their HPLC elution times, UV absorbance spectra, $\mathrm{ES}^{-}$-MS mass spectra, and in some cases proton NMR spectra (Table 1). The phenolics belonged to two classes: four were hydroxycinnamic acid amides and four were derivatives of acetophenone. The elution times, UV spectra, and $\mathrm{ES}^{-}$-MS spectra of peaks 1 and 2 (Table 1) were identical to those of authentic standards of $N-(E)$ caffeoylputrescine $\left(\mathrm{C}_{13} \mathrm{H}_{18} \mathrm{~N}_{2} \mathrm{O}_{3}=250\right.$; Fig. 1, structure 1) and $N$-(E)-feruloylputrescine $\left(\mathrm{C}_{14} \mathrm{H}_{20} \mathrm{~N}_{2} \mathrm{O}_{3}=264\right.$; Fig. 1, structure 2), respectively. The elution time, UV spectrum, ES $^{-}$-MS spectrum, and ${ }^{1} \mathrm{H}-\mathrm{NMR}$ spectrum of peak 8 were identical to those of an authentic standard of $N-(E)$ feruloyltyramine $\left(\mathrm{C}_{18} \mathrm{H}_{19} \mathrm{NO}_{4}=313\right.$; Fig. 1 , structure 8). $\mathrm{ES}^{-}$-MS spectra of peaks 7 and 8 were indistinguishable, but the UV spectra were markedly different, suggesting that peak 7 is the cis isomer of peak $8, N$-(Z)-feruloyltyramine $\left(\mathrm{C}_{18} \mathrm{H}_{19} \mathrm{NO}_{4}=313\right.$; Fig. 1, structure 7). This was confirmed by the ${ }^{1} \mathrm{H}-\mathrm{NMR}$ signal for the olefinic proton on $\mathrm{C} 8$, a doublet with $J=12.5 \mathrm{~Hz}$ at $5.80 \mathrm{ppm}$, indicative of a cis double bond between $\mathrm{C} 7$ and $\mathrm{C} 8$ [21].

Nicotiana tabacum phenolics in HPLC peaks 3, 4, 5, and 6 were identified as acetophenone derivatives (Table 1 and Fig. 1). The elution times, UV spectra, and $\mathrm{ES}^{-}$-MS spectra of peaks 5 and 6 were identical to those of authentic standards of 4-hydroxyacetophenone $\left(\mathrm{C}_{8} \mathrm{H}_{8} \mathrm{O}_{2}=136\right.$; Fig. 1, structure 5) and 3,5-dimethoxy-4-hydroxyacetophenone (acetosyringone; $\mathrm{C}_{10} \mathrm{H}_{12} \mathrm{O}_{4}=196$; Fig. 1, structure 6), respectively. In addition, the $\mathrm{ES}^{-}$-MS and ${ }^{1} \mathrm{H}-\mathrm{NMR}$ spectra obtained for peak 6 were in accord with those recently reported for acetosyringone [9]. The UV spectra of peaks

Table 1

Hydroxycinnamic acid amide conjugates and acetophenone derivatives released from cultured cells of $N$. tabacum and quantified by HPLC-UV analysis

\begin{tabular}{|c|c|c|c|c|c|}
\hline & \multirow[t]{2}{*}{ Elution time (min) } & \multirow{2}{*}{$\begin{array}{l}\text { UV Abs. maxima } \\
(210-330 \mathrm{~nm})\end{array}$} & \multicolumn{2}{|c|}{$\mathrm{ES}^{-}-\mathrm{MS}$ ions } & \multirow[t]{2}{*}{ Identification } \\
\hline & & & $\overline{[\mathrm{M}-1]^{-}}$ & $100 \% \mathrm{RI}^{\mathrm{a}}$ & \\
\hline \multicolumn{6}{|c|}{ Hydroxycinnamic acid amides } \\
\hline Peak 1 & 9.6 & $319,294(\mathrm{sh})$ & 249 & 249 & $N$ - $(E)$-caffeoylputrescine \\
\hline Peak 2 & 13.8 & $318,294(\mathrm{sh})$ & 263 & 263 & $N$-(E)-feruloylputrescine \\
\hline Peak 7 & 28.5 & $276,305(\mathrm{sh})$ & 312 & 312 & $N$-(Z)-feruloyltyramine \\
\hline Peak 8 & 30.9 & $318,293(\mathrm{sh})$ & 312 & 312 & $N$-(E)-feruloyltyramine \\
\hline \multicolumn{6}{|c|}{ Acetophenone derivatives } \\
\hline Peak 3 & 20.2 & 301,215 & 211 & 196 & $\alpha$-Hydroxyacetosyringone \\
\hline Peak 4 & 22.4 & 299,215 & 181 & 166 & 5-Hydroxyacetovanillone $\mathrm{e}^{\mathrm{b}}$ \\
\hline Peak 5 & 24.7 & 276,220 & 135 & 135 & 4-Hydroxyacetophenone \\
\hline Peak 6 & 25.9 & 300,215 & 195 & 180 & Acetosyringone \\
\hline
\end{tabular}

\footnotetext{
${ }^{\text {a }}$ RI, relative intensity.

b Tentative identification based on HPLC, LC-MS, and UV absorbance data.
} 


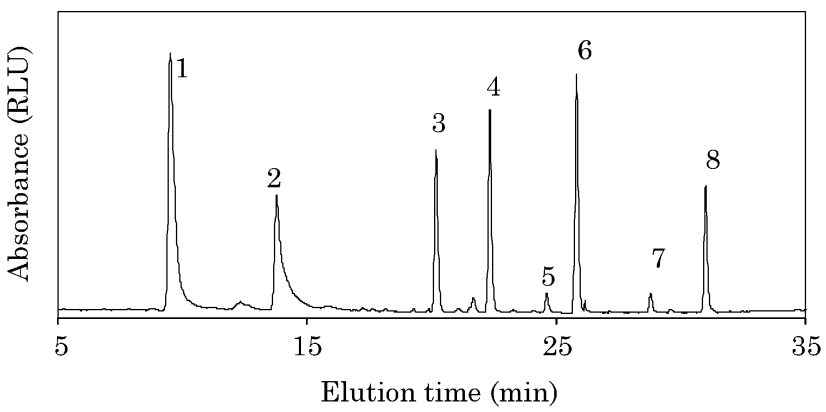

Hydroxycinnamic acid amide derivatives
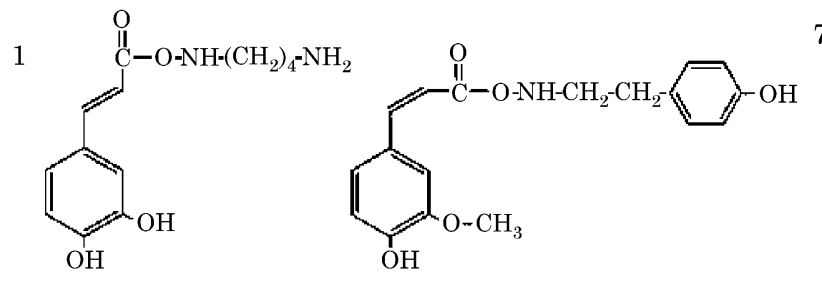

(II)

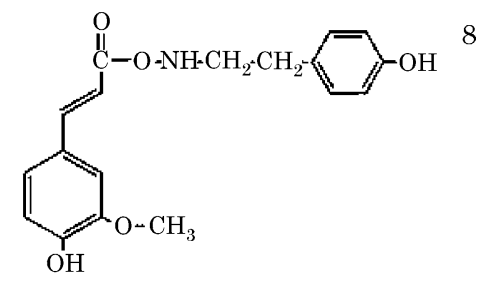

Acetophenone derivatives
3<smiles>COc1cc(C(=O)CO)cc(OC)c1O</smiles><smiles>CC(=O)c1ccc(O)cc1</smiles>
8 atom to the alpha carbon and peak 4 differs from acetosyringone by the loss of a methyl group from either of the symmetric methoxy groups on the phenyl ring. Hence, peak 3 was identified as $\boldsymbol{\alpha}$-hydroxyacetosyringone $\left(\mathrm{C}_{10} \mathrm{H}_{12} \mathrm{O}_{5}=212\right.$; Fig. 1, structure 3) and peak 4 was tentatively identified as 3-methoxy-4,5-dihydroxyacetophenone (5-hydroxyacetovanillone; $\mathrm{C}_{9} \mathrm{H}_{10} \mathrm{O}_{4}=182$; Fig. 1, structure 4). Peaks 5 (4-hydroxyacetophenone) and 7 $(N-(Z)$-feruloyltyramine) were much less abundant than the other six peaks and are therefore not mentioned further in the results.

\subsection{Phenolic accumulation in suspensions treated with P. syringae isolates}

The response of tobacco cell suspensions, $0.05 \mathrm{~g} \mathrm{ml}^{-1}$, to $P$. syringae strains $\mathrm{WT}(\mathrm{HR}+)$ or $\mathrm{B} 7(\mathrm{HR}-)$, $10^{7} \mathrm{cfu} \mathrm{ml}^{-1}$, was followed over a $10 \dagger 12 \mathrm{~h}$ period (Fig. 2). The accumulation of extracellular phenolics was monitored by HPLC-UV analysis of the extracellular fluid.
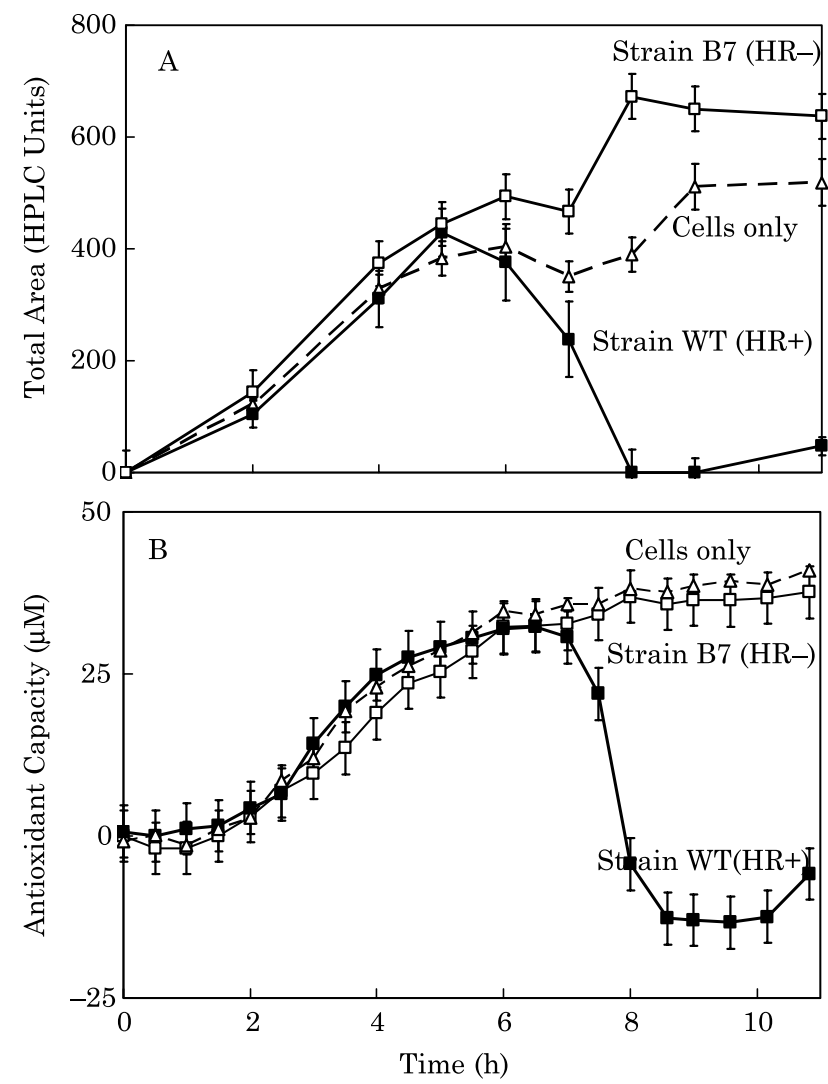

Fig. 2. Time course monitoring changes in extracellular phenolic accumulation and antioxidant capacity. Two-day-old tobacco cell suspensions, $0.05 \mathrm{~g} \mathrm{ml}^{-1}$, were treated with $P$. syringae strains, $10^{7} \mathrm{cfu} \mathrm{ml}^{-1}$. Samples of treated tobacco cell suspensions were removed and analyzed: (A) total peak area from HPLC-UV chromatogram; (B) antioxidant capacity. See Section 2 for details. The data shown represent the results of one experiment with two replicates of each treatment. The experiment was repeated two additional times with similar results. The error bars represents $1 \mathrm{SD}$. 
At this inoculum concentration, the extracellular phenolics in tobacco suspensions increased at about the same rate in both control and bacteria-treated cell suspensions during the first 4-5 h (Fig. 2A). The extracellular phenolics in control and strain B7 $(\mathrm{HR}-)$ treated suspensions continued to increase, except for a slight dip at $7 \mathrm{~h}$ in peak area, and reached a maximum after 8-9 h. Conversely, the extracellular phenolics of strain WT $(\mathrm{HR}+)$ treated suspensions began to decrease rapidly after $6 \mathrm{~h}$. There were no detectable HPLC peaks in the WT $(\mathrm{HR}+)$ treated suspensions at $8 \mathrm{~h}$, however, by $11 \mathrm{~h}$ extracellular phenolics began to reappear (Fig. 2A).

The loss of extracellular phenolics in tobacco cell suspensions treated with strain WT $(\mathrm{HR}+)$ was concurrent with the onset of an oxidative burst in these cells. This was determined by monitoring the extracellular antioxidant capacity of these suspensions by titration with $\mathrm{H}_{2} \mathrm{O}_{2}$ (Fig. 2B). Control and B7 treated suspensions increased in antioxidant capacity, nearly $40 \mu \mathrm{M}$ after $10 \mathrm{~h}$, as the concentration of extracellular phenolics increased. The WT $(\mathrm{HR}+)$ treated suspensions increased in antioxidant capacity to about $35 \mu \mathrm{M}$ by $6 \mathrm{~h}$ after which there was a sudden decrease in extracellular antioxidant capacity to $-15 \mu \mathrm{M}$. This decrease in antioxidant capacity is indicative of an oxidative burst which appears to be over by $11 \mathrm{~h}$ when antioxidant capacity starts to increase again. The extracellular prooxidants produced, such as $\mathrm{H}_{2} \mathrm{O}_{2}$, oxidize the available phenolics and any excess prooxidant is indicated as negative antioxidant capacity in this assay [5].

The phenolic compositions of the different treatments were compared after $9 \mathrm{~h}$ (Fig. 3A). Five major phenolics were identified in the extracellular fluid of cell suspensions from 2-day-old tobacco cultures. Two of the phenolics were conjugates of putrescine and three were acetophenone derivatives. The phenolic compositions of the control and strain B7 (HR-) treatments were qualitatively similar, but the latter was generally $10-20 \%$ higher in concentration. As a result of the oxidative burst, the strain WT $(\mathrm{HR}+)$ treatment had no detectable extracellular phenolics after $9 \mathrm{~h}$.

The changes in the concentration of individual phenolics during the $11 \mathrm{~h}$ incubation period generally followed one of three patterns in the control and strain B7 $(\mathrm{HR}-)$ treatments (Fig. 3B). The two putrescine conjugates increased immediately reaching maximum levels by $4-5 \mathrm{~h}$ and then after a slight decrease stabilized over the remainder of the monitored period as shown for caffeoylputrescine. The three acetophenone derivatives increased after nearly a $2 \mathrm{~h}$ delay and then followed two different patterns. The 5-hydroxyacetovanillone derivative reached a maximum at about $5 \mathrm{~h}$ and then decreased to undetectable levels by $9 \mathrm{~h}$ in control suspension cells; in strain B7 (HR-) treatments it decreased but was still detectable. The other acetophenone derivatives increased at a nearly constant rate for the remainder of the $11 \mathrm{~h}$ period as shown for acetosyringone. The decrease in the putrescine conjugates and 5-hydroxyacetovanillone accounts for the above-mentioned
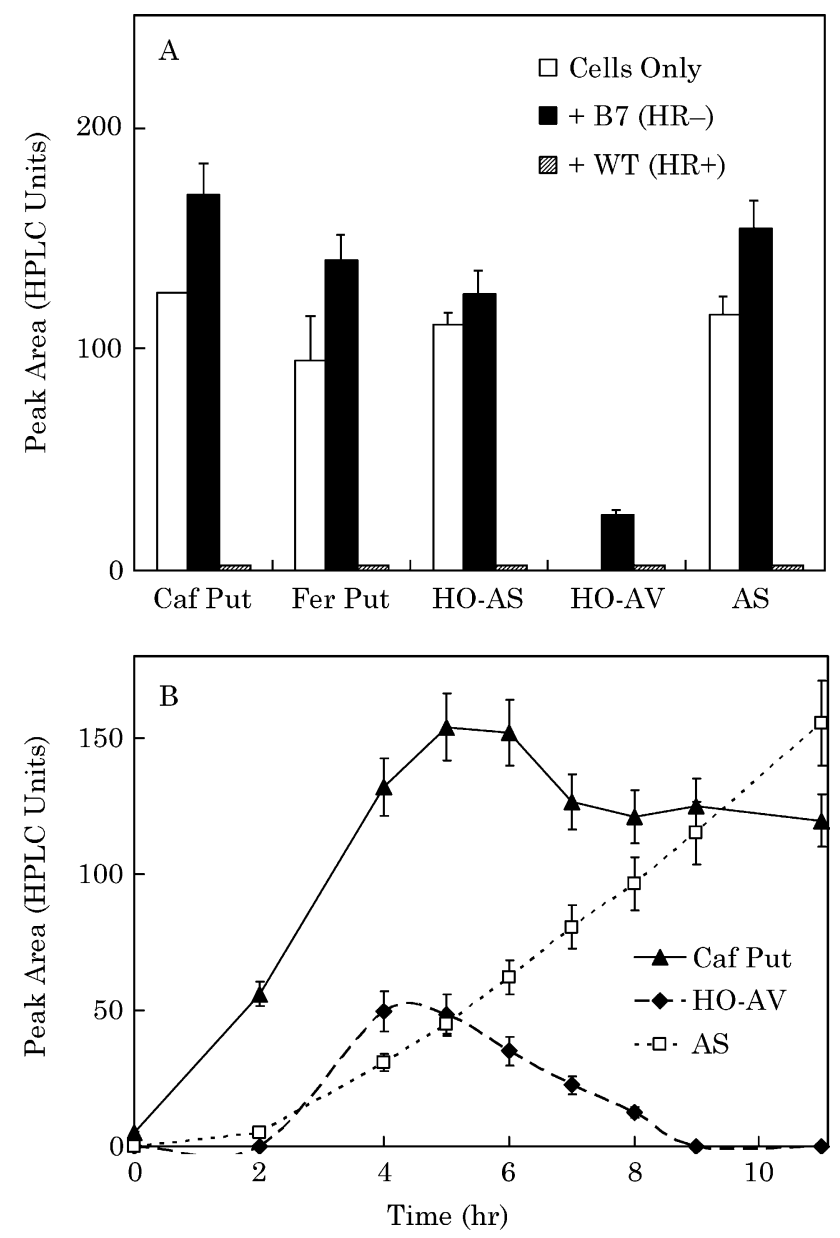

Fig. 3. Major extracellular phenolics in cell suspensions from 2-day-old tobacco cultures, $0.05 \mathrm{~g} \mathrm{ml}^{-1}$, treated with $P$. syringae strains, $10^{7} \mathrm{cfu} \mathrm{ml}^{-1}$. (A) Major extracellular phenolics after $9 \mathrm{~h}$ of incubation, based on HPLC-UV analysis. (B) Different patterns of accumulation of phenolics in the extracellular fluid of untreated tobacco cell suspensions. See Section 2 for details. The data shown represent the results of one experiment with two replicates of each treatment. The experiment was repeated two additional times with similar results. The error bars represents 1 SD. (Caf Put, caffeoylputrescine; Fer Put, feruloylputrescine; HO-AS, $\alpha$-hydroxyacetosyringone; HO-AV, 5-hydroxyacetovanillone; AS, acetosyringone).

dip in total peak area at $6-7 \mathrm{~h}$ in the control and strain $\mathrm{B} 7$ $(\mathrm{HR}-$ ) treatments (Fig. 2A).

\subsection{Effect of bacterial inoculum concentration on extra- cellular phenolic accumulation}

Previous experience with this tobacco cell suspension model system has shown that varying the bacterial inoculum concentration will strongly influence many responses associated with the plant-bacterial interaction $[3,6]$. Therefore we examined the effect of bacterial inoculum concentration on the accumulation of extracellular phenolics over a $6 \mathrm{~h}$ period using cells from 2-day-old tobacco cultures (Fig. 4A). Only strain B7 (HR-) was used since it induces 

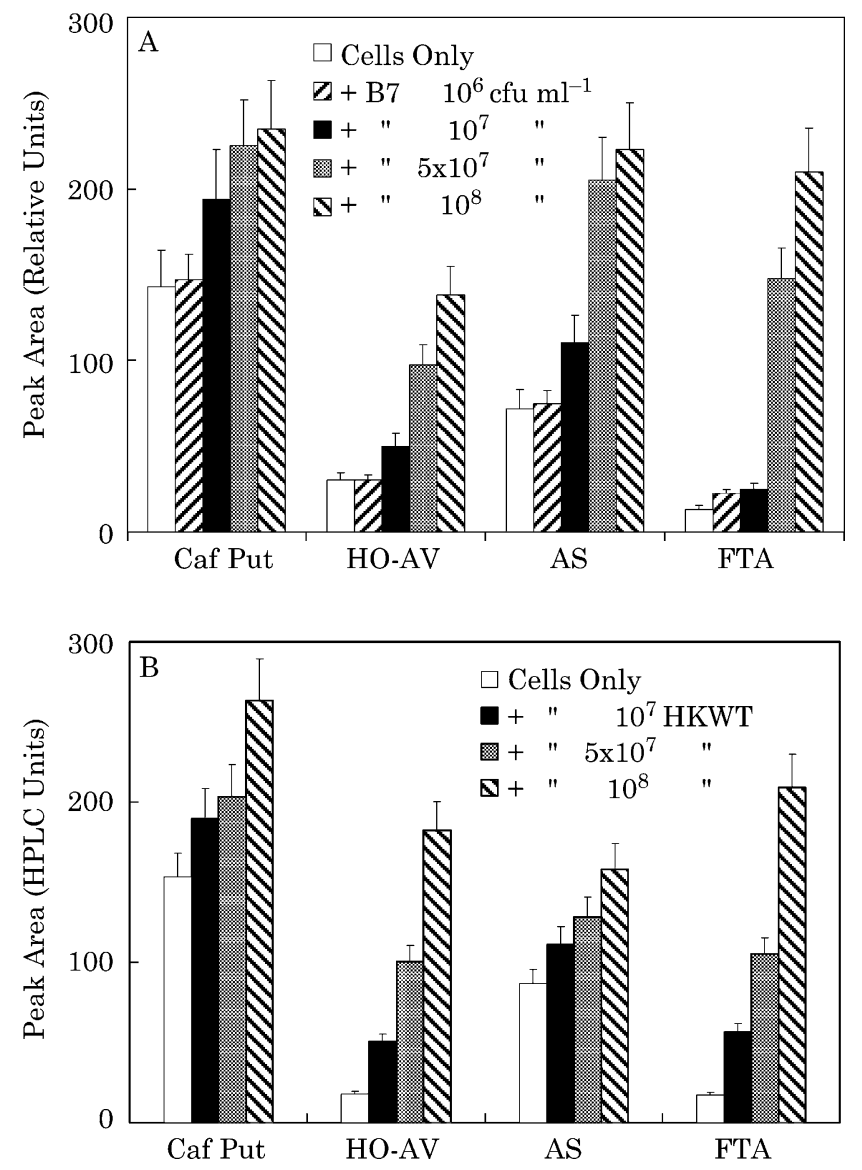

Fig. 4. Effect of inoculum concentration of live or heat-killed bacteria on the composition of extracellular phenolics in tobacco cell suspensions. Two-day-old tobacco cell suspensions, $0.05 \mathrm{~g} \mathrm{ml}^{-1}$, were treated with designated concentrations of $(\mathrm{A})$ strain $\mathrm{B} 7(\mathrm{HR}-)$ or $(\mathrm{B})$ heat-killed preparations (HKWT) of strain WT $(\mathrm{HR}+)$ for $6 \mathrm{~h}$. See Section 2 for details. The data shown represent the results of two experiments, each with two replicates of each treatment. The error bars represents 1 SD. (Caf Put, caffeoylputrescine; HO-AV, 5-hydroxyacetovanillone; AS, acetosyringone; FTA, feruloyltyramine). accumulation of phenolics without production of the oxidative burst. As the inoculum concentration increased from $10^{6}$ to $10^{8} \mathrm{cfu} \mathrm{ml}^{-1}$, the concentration of many of the extracellular phenolics increased in an incremental manner similar to caffeoylputrescine with an overall increase of about $50 \%$ at the highest inoculum concentration of $10^{8} \mathrm{cfu} \mathrm{ml}^{-1}$. The concentration of three phenols, hydroxyacetovanillone, acetosyringone and feruloyltyramine, responded more dramatically increasing 3-, 4- and 8-fold, respectively, as the inoculum concentration increased from $10^{6}$ to $10^{8} \mathrm{cfu} \mathrm{ml}^{-1}$.

To see if live bacteria were required for the increased accumulation of extracellular phenolics, we treated tobacco suspensions with heat-killed $P$. syringae strain WT $(\mathrm{HR}+)$ equivalent to $10^{7}, 5 \times 10^{7}$, and $10^{8} \mathrm{cfu} \mathrm{ml}^{-1}$ (Fig. 4B). In general, the response after $6 \mathrm{~h}$ incubation was similar to that associated with live bacteria. The concentration of extracellular phenolics in tobacco suspensions increased as the concentration of the heat-killed bacteria treatment increased. The most dramatic change in concentration occurred with hydroxyacetovanillone and feruloyltyramine, which increased 9- to 10-fold at the highest concentration of heat-killed bacteria compared to untreated tobacco cells.

\subsection{Effect of tobacco cell age and density on extracellular phenolic accumulation}

During attempts to accumulate large quantities of these phenolics for identification, we found that increased tobacco suspension cell density did not always yield increased phenolics. Tobacco cell suspensions of density $0.05,0.1$ and $0.2 \mathrm{~g} \mathrm{ml}^{-1}$, were incubated $6 \mathrm{~h}$ with strain B7 $\left(\mathrm{HR}-\right.$ ), $10^{7} \mathrm{cfu} \mathrm{ml}^{-1}$ (Fig. 5). Based on the total peak area, when the suspension cell density was doubled to $0.1 \mathrm{~g} \mathrm{ml}^{-1}$ the extracellular phenolics increased only $34 \%$. Increasing the cell density further to $0.2 \mathrm{~g} \mathrm{ml}^{-1}$ surprisingly, caused the concentration of total phenolics to drop

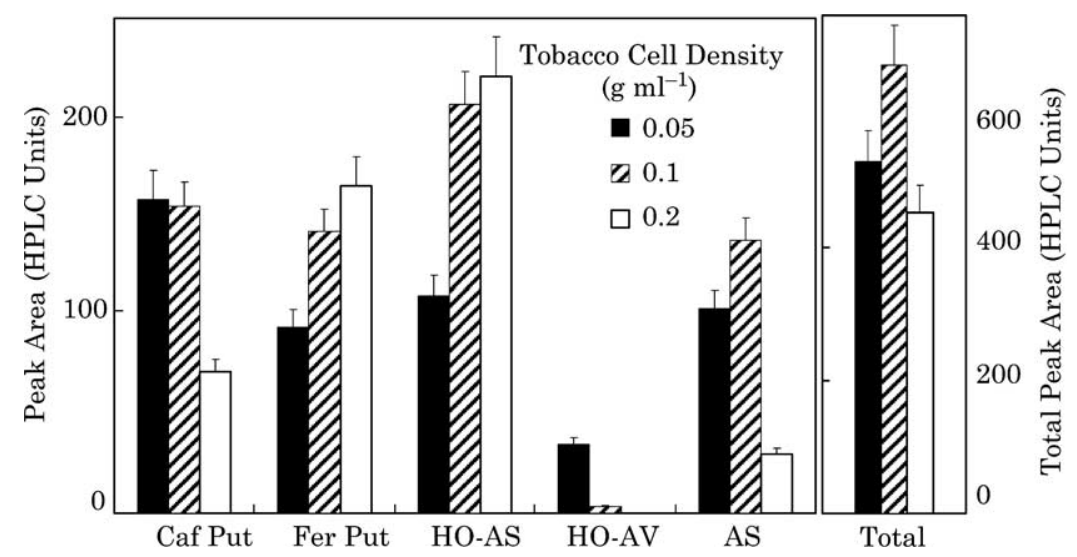

Fig. 5. Effect of tobacco suspension cell density on the composition of extracellular phenolics. Two-day-old tobacco cell suspensions of different cell densities were treated with $P$. syringae strain, $10^{7} \mathrm{cfu} \mathrm{ml}^{-1}$, for $6 \mathrm{~h}$. Only phenolics that changed substantially with cell density are shown. The total peak area includes all phenolics, shown and not shown in the figure. See Section 2 for details. The data shown represent the results of two experiments, each with two replicates of each treatment. The error bars represents 1 SD. (Caf Put, caffeoylputrescine; Fer Put, feruloylputrescine; HO-AS, $\alpha$-hydroxyacetosyringone; HO-AV, 5-hydroxyacetovanillone; AS, acetosyringone). 


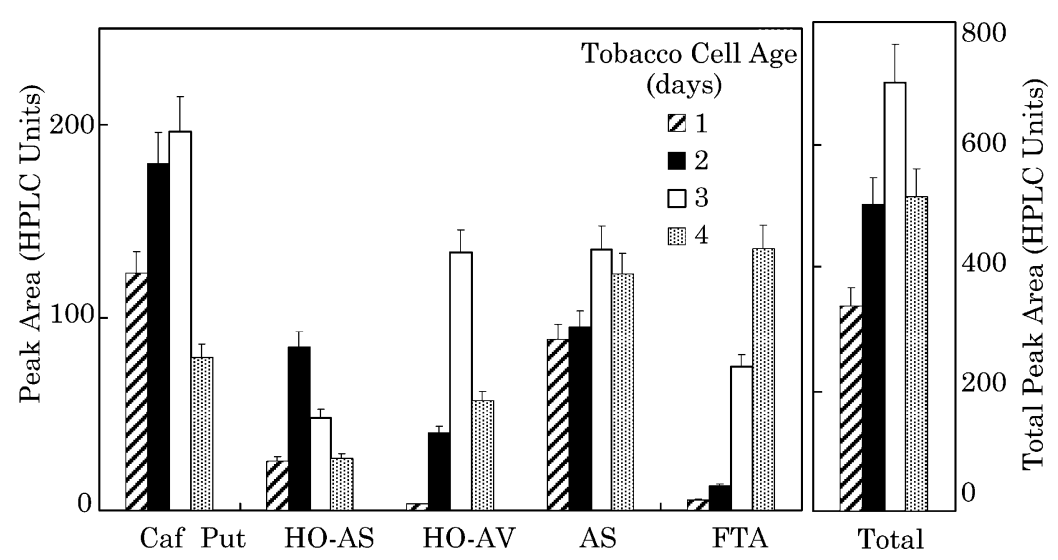

Fig. 6. Effect of tobacco cell age on the composition of extracellular phenolics. Tobacco cell suspensions were prepared from 1- to 4-day-old tobacco cultures, $0.05 \mathrm{~g} \mathrm{ml}^{-1}$, and treated with $P$. syringae strain, $10^{7} \mathrm{cfu} \mathrm{ml}^{-1}$, for $6 \mathrm{~h}$. Only phenolics that changed substantially with cell age are shown. The total peak area includes all phenolics, shown and not shown in the figure. See Section 2 for details. The data shown represent the results of two experiments, each with two replicates of each treatment. The error bars represents 1 SD. (Caf Put, caffeoylputrescine; HO-AS, $\alpha$-hydroxyacetosyringone; HO-AV, 5-hydroxyacetovanillone; AS, acetosyringone; FTA, feruloyltyramine).

below levels in the $0.05 \mathrm{~g} \mathrm{ml}^{-1}$ density. The individual phenolics did not necessarily follow this pattern (Fig. 5). For example, the concentration of feruloylputrescine and $\alpha$-hydroxyacetosyringone increased with cell density, whereas the concentration of caffeoylputrescine decreased with increased cell density. The concentration of acetosyringone decreased more than $70 \%$ at the higher cell density.

Previous experience with these suspension cells has indicated that cell age is critical to obtain the expected differential responses with the $P$. syringae pathovars and strains; therefore we determined the effect of cell age on extracellular phenolic accumulation after $6 \mathrm{~h}$ incubation (Fig. 6). To simplify the figure only phenolics greatly affected by cell age were included. Some of the dominant phenolics that accumulate in cell suspensions from 2-day-old tobacco cultures do not maintain these levels in cell suspensions from 4-day-old tobacco cultures, for example caffeoylputrescine and $\alpha$-hydroxyacetosyringone. Other phenolics, such as 5-hydroxyacetovanillone and feruloyltyramine, which is normally a minor component, accumulate to higher levels in 3- or 4-day-old cells and become the dominant phenolics.

\section{Discussion}

This study characterized the accumulation of extracellular phenolics in tobacco cell suspensions after treatment with a bacterial pathogen. Two groups of phenolics were identified: the acetophenone group consisted of hydroxyacetosyringone, hydroxyacetovanillone, hydroxyacetophenone, and acetosyringone; and the hydroxycinnamic acid amide group consisted of caffeoylputrescine, feruloylputrescine, and feruloyltyramine (Table 1, Fig. 1). Most of the extracellular phenolics were found to accumulate in untreated tobacco cell suspensions, however, the rate and magnitude of accumulation as well as different phenolics increased in the presence of $P$. syringae strain B7 (HR-)
(Fig. 4). The rate of accumulation and concentration of the extracellular phenolics in tobacco cell suspensions increased with higher inoculum concentrations of either live or heat-killed bacteria. Other factors that affected the accumulation of extracellular phenolics in tobacco cell suspensions were the tobacco cell density and age. Interestingly, doubling the cell density of tobacco suspensions from 0.1 to $0.2 \mathrm{~g} \mathrm{ml}^{-1}$ resulted in a decrease in accumulation rate and concentration of extracellular phenolics (Fig. 5). The age of the tobacco cells affected the qualitative and quantitiative makeup of the extracellular phenolics, with the relatively minor component, feruloyltyramine, increasing dramatically as cells age (Fig. 6). When tobacco cell suspensions were treated with $P$. syringae strain WT $(\mathrm{HR}+)$, the extracellular phenolics started to accumulate similarly to strain B7 $(\mathrm{HR}-)$ treatments until the onset of an oxidative burst (Fig. 2). During the oxidative burst, the concentration of the extracellular phenolics in these tobacco suspensions decreased and became undetectable.

The phenolics identified in this study fall into two groups of metabolites, the acetophenones and hydroxycinnamic acid amides, that are associated with bioactivity in both plant and animal cells as established by several recent reviews $[8,11,24,31]$. The acetophenone derivatives (Fig. 1) have been linked to regulation of critical gene expression and metabolite production in several host-pathogen interactions $[12,19]$. We recently reported that increasing the concentration of extracellular acetosyringone in tobacco cell suspensions treated with $P$. syringae WT $(\mathrm{HR}+)$ caused an oxygen uptake response, unique to incompatible interactions, to occur as much as $1.5 \mathrm{~h}$ earlier. The hydroxycinnamic acid amides, which include the conjugated putrescine and tyramine derivatives (Fig. 1B) have properties associated with polyamines, which are derived from arginine and are positively charged at physiological $\mathrm{pH}$. Polyamines are ubiquitous in nature and are known to bind 
to negatively charged molecules such as nucleic acids and cell walls [18]. Although their production and presence is strongly tied to several physiological processes, their specific putative roles remain controversial [11,31].

Numerous studies have demonstrated that periods of oxidative stress occur during the course of plant-pathogen interactions [1]. As shown in this study (Fig. 2), this event would oxidize redox-sensitive phenolics, affecting their concentration as well as any associated bioactivity which could influence the outcome of the interaction. There are several studies relating redox sensitivity to bioactivity in phenols. A strong correlation has been found between redox potentials $\left(\mathrm{E}^{\mathrm{o}}\right)$ and the inhibitory effects of naphthoquinones on Epstein-Barr virus activation, which could lead to cancer [13]. The more positive the redox potential the stronger the anti-tumor promoting effect. They point out that changes in $\mathrm{pH}$ would alter the redox potential and therefore alter the bioactivity of the phenolic [28]. Loo [17] in a recent review discussed several redox-sensitive mechanisms in which plant phenolics are used as chemopreventive agents to prevent cancer cell proliferation. The sites include redox-sensitive regulation of kinases as well as transcription factors. These studies also point out the fact that phenolics when oxidized give up an electron and can become strong oxidants which in the right location could interact with regulatory molecules and trigger or suppress a particular mechanism.

In summary, this study demonstrated that plant suspension cells actively and rapidly accumulate phenolics in the extracellular environment during the first several hours of the plant-bacterial interaction. Preliminary experiments examining phenolics from extracellular fluids of leaves suggest similar events may occur in planta. Because these phenolics are in direct contact with the bacterial pathogens and because of their reported bioactivity $[12,16,20,26,30]$, it is reasonable to speculate that they play a pivotal role in pathogenesis. Our goal now is to determine whether these extracellular phenolics have bioactive properties that may play a significant role in our cell-suspension-bacterial interaction.

\section{Acknowledgements}

We wish to thank Dr Walter F. Schmidt and Mrs Ute Klingebiel, USDA, ARS, Environmental Quality Laboratory for acquisition of the ${ }^{1} \mathrm{H}-\mathrm{NMR}$ spectra.

\section{References}

[1] Apel K, Hirt H. Rective oxygen species: metabolism, oxidative stress, and signal transduction. Annu Rev Plant Biol 2004;55:373-99.

[2] Baker CJ, Atkinson MM, Collmer A. Concurrent loss in Tn5 mutants of Pseudomonas syringae pv. syringae of the ability to induce the hypersensitive response and host plasma membrane $\mathrm{K}+/ \mathrm{H}+$ exchange in tobacco. Phytopathology 1987;77:1268-72.

[3] Baker CJ, Harmon GL. A noninvasive technique for monitoring peroxidative and $\mathrm{H}_{2} \mathrm{O}_{2}$-scavenging activities during interactions between bacterial plant pathogens and suspension cells. Plant Physiol 1995;108:353-9.

[4] Baker CJ, Mock NM. An improved method for monitoring cell death in cell-suspension and leaf disc assays using Evans Blue. Plant Cell Tiss Organ Cult 1994;39:7-12.

[5] Baker CJ, Mock NM. A method to detect oxidative stress by monitoring changes in the extracellular antioxidant capacity in plant suspension cells. Physiol Mol Plant Pathol 2004;25:255-61.

[6] Baker CJ, Mock NM, Whitaker BD, Roberts DP, Rice CP, Deahl KL, et al. Involvement of acetosyringone in plant-pathogen recognition. Biochem Biophys Res Commun 2005;328:130-6.

[7] Baker CJ, O'Neill NR, Deahl KL, Lydon J. Continuous production of extracellular antioxidants in suspension cells attenuates the oxidative burst detected in plant microbe interactions. Plant Physiol Biochem 2002;40:641-4.

[8] Berthelot K, Buret D, Guerin B, Delay D, Negrel J, Delmotte F. Vir-gene-inducing activities of hydroxycinnamic acid amides in Agrobacterium tumefaciens. Phytochemistry 1998;49:1537-48.

[9] Blount J, Masoud S, Sumner L, Huhman D, Dixon R. Over-expression of cinnamate 4-hydroxylase leads to increased accumulation of acetosyringone in elicited tobacco cell-suspension cultures. Planta 2002;214:902-10

[10] Dixon R, Palva N. Stress-induced phenylpropanoid metabolism. Plant Cell 1995;7:1085-97.

[11] Facchini PJ, Hagel J, Zulak KG. Hydroxycinnamic acid amide metabolism: physiology and biochemistry. Can J Bot 2002;80: 577-89.

[12] Huang SS, Tsai MC, Chih CL, Hung LM, Tsai SK. Resveratrol reduction of infarct size in Long-Evans rats subjected to focal cerebral ischemia. Life Sci 2001;69:1057-65.

[13] Koyama J, Morita I, Kobayashi N, Osakai T, Hotta H, Takayasu J, et al. Correlation of redox potentials and inhibitory effects on EpsteinBarr virus activation of naphthoquinones. Cancer Lett 2003;201: 25-30.

[14] Lee S, Chung H, Lee I, Oh S, Yoo I. Phenolics with inhibitory activity on mouse brain monoamine oxidase (MAO) from whole parts of Artemisia vulgaris L. (Mugwort). Food Sci Biotechnol 2000;9: 179-82.

[15] Lee Y, Jin S, Sim W, Nester E. Genetic evidence for direct sensing of phenolic compounds by the VirA protein of Agrobacterium tumefaciens. Proc Natl Acad Sci USA 1995;92:12245-9.

[16] Lee Y, Jin S, Sim W, Nester E. The sensing of plant signal molecules by Agrobacterium: genetic evidence for direct recognition of phenolic inducers by the VirA protein. Gene 1996;179:83-8.

[17] Loo G. Redox-sensitive mechanisms of phytochemical-mediated inhibition of cancer cell proliferation. J Nutr Biochem 2003;14:64-73.

[18] Martin-Tanguy J. Conjugated polyamines and reprodcutive development: biochemical, molecular and physiological approaches. Physiol Plant 1997;100:675-88

[19] Miguel MG, Barroso JG. Accumulation of stress metabolites in cell suspension cultures of Hyoscyamus albus. Phytochemistry 1994;35: $371-5$.

[20] Mo Y, Geibel M, Bonsall RF, Gross DC. Analysis of Sweet Cherry (Prunus avium L.) leaves for plant signal molecules that activate the syrB gene requried for synthesis of the phytotoxin, syringomycin, by Pseudomonas syringae pv. syringae. Plant Physiol 1995;107:603-12.

[21] Morishita H, Iwahashi H, Osaka N, Kido R. Chromatographic separation and identification of naturally occurring chlorogenic acids by $1 \mathrm{H}$ nuclear magnetic resonance spectroscopy and mass spectrometry. J Chromatogr 1984;315:253-60.

[22] Muller AA, Reiter SA, Heider KG, Wagner H. Plant-derived acetophenones with antiasthmatic and anti-inflammatory properties: inhibitory effects on chemotaxis, right angle light scatter and actin polymerization of polymorphonuclear granulocytes. Planta Med 1999;65:590-4.

[23] Nicholson RL, Hammerschmidt R. Phenolic compounds and their role in disease resistance. Ann Rev Phytopathol 1992;30:369-89. 
[24] Parr AJ, Bolwell GP. Phenols in the plant and in man. The potential for possible nutritional enhancement of the diet by modifying the phenols content or profile. J Sci Food Agric 2000;80:985-1012.

[25] Pennington JAT. Food composition databases for bioactive food components. J Food Compos Anal 2002;15:419-34.

[26] Peters NK, Frost JW, Long SR. A plant flavone, luteolin, induces expression of Rhizobium meliloti nodulation genes. Science 1986; 233:977-80.

[27] Robards K. Strategies for the determination of bioactive phenols in plants, fruit and vegetables. J Chromatogr A 2003;1000:657-91.

[28] Schafer FQ, Buettner GR. Redox environment of the cell as viewed through the redox state of the glutathione disulfide/glutathione couple. Free Radic Biol Med 2001;30:1191-212.
[29] Vance CP, Kirk TK, Sherwood RT. Lignification as a mechanism of disease resistance. Ann Rev Phytopathol 1980;18:259-88.

[30] Von Roepenack-Lahaye E, Newman M, Schornacki S. p-coumarolynoradrenaline, a novel plant metabolite implicated in tomato defense against pathogens. J Biol Chem 2003;278:43373-83.

[31] Walters DR. Polyamines in plant-microbe interactions. Physiol Mol Plant Pathol 2000;57:137-46.

[32] Whitaker BD, Stommel JR. Distribution of hydroxycinnamic acid conjugates in fruit of commercial eggplant (Solanum melongena L.) cultivars. J Agric Food Chem 2003;51:3448-54.

[33] Zhang XZ, Schmidt RE, Ervin EH, Doak S. Creeping bentgrass physiological responses to natural plant growth regulators and iron under two regimes. Hortscience 2002;37:898-902. 